\title{
Four Times Daily
}

National Cancer Institute

\section{Source}

National Cancer Institute. Four Times Daily. NCI Thesaurus. Code C64530.

Four times per day. 